Metodički obzori 6(2011)2

Review article

UDK: 371.695:373.3

Received: 30. 8. 2010.

\title{
GAMES AS A TOOL FOR THE PROMOTION OF LEARNING. A SURVEY IN PRIMARY SCHOOL
}

\author{
Magda Sclaunich, researcher \\ Faculty of Science of Education at Trieste (Italy) \\ e-mail: sclaunic@units.it
}

S u $\boldsymbol{m} \boldsymbol{m} \boldsymbol{a} \boldsymbol{r} \boldsymbol{y}$

This study proposes a particular didactic methodological strategy, the game, which has been dealt with at three different levels.

Level 1. At the first level I have tried to describe, in synthesis, some theoretical-conceptual features of the game. A historical overview looks back at some authors, starting with Froebel, who, in the sphere of the history of education, have recognised in the game a didactic-educative value, and have proposed it as a valid tool in promoting and strengthening the growth of the subjects.

Level 2. At the second level it was considered useful to analyse the text of the policy document currently in force in Italy (the "Directions for the Curriculum") to understand what importance this document attributes to the game as a didactic tool.

Level 3. At the third level this topic was dealt with in an empirical perspective. A field study was carried out which involved teachers and pupils of an entire school in order to understand how important the game is considered to be and how much it is actually used as a didactic tool by the teachers within the primary school. Two multiple choice questionnaires were prepared, one for the pupils and one for the teachers.

The data revealed that:

- Both pupils and teachers agree on the fact that the game is a useful tool in the didactic sphere.

- The mathematics teachers have a much more favourable attitude towards the use of the game as a didactic tool than their colleagues who teach Italian.

- The pupils recognise that the game is useful not only in the first grades, when they are still "little", but it is a valid tool which the teachers can make use of in their didactic activities independently of the grade in which they are teaching. the teachers.

- The game, according to what the pupils say, is a tool which is used by

- The teachers make more use of the game in the first grades.

- The teachers who have been working longer in the profession, and therefore are more "expert", contrary to what one might think, prove more favourable to the use of the game than their younger and more inexpert colleagues.

Key words: game, learning, primary school, school programmes, didactic strategies. 


\section{Games as a tool for the promotion of learning in a historical perspective}

What do we mean when we speak of "the game"? Different answers have been given to this question through time because the game is an "object" which is difficult to define in a precise and unambiguous way; for this reason, over the centuries the game has become an object of study in different fields of discipline.

Philosophical reflections and anthropological, ethological, sociological, and even psychological studies have brought scientists belonging to different and opposing schools to put forward numerous theories about the game, and to define specific keys for interpreting the activity of playing games. It is interesting to trace the essential tendencies which have developed from the nineteenth century to today.

In the nineteenth century the importance of the game was emphasised, and it was seen as a spontaneous and creative activity, as a linking element between nature and humanity, necessary in achieving the vision of a united, animated and animating world, that of Romanticism.

Within this framework the game can be considered as a tool which has persisted through all the ages of man. The game is given an aesthetic and ethical relevance which represents the act of liberty towards which man tends.

An integral contribution as regards this position, and particularly significant for our work, consists in understanding the game as a fundamental instrument for learning of the child (Froebel, 1960), the game in this perspective constitutes the highest grade of infant development, since it is a free manifestation of the interior world, it is the purest and most spiritual product of mankind in its infant years.

Particularly useful for this argument are the studies conducted in psychological research which have identified in the game a learning function for the development of the mind and personality. On this subject it is significant to recall, briefly, the opinions of three authors who have made a notable contribution in this direction: Piaget, Vygotsky and Bruner.

Piaget $(1967,1972)$, in his research on mental development in children, formulated a theory on game, closely linked to the evolution of intelligence. According to this author game must be placed within the framework of the general working of the mind, in that it is a tool which allows the child to assimilate and adapt the world of experience to his own mental dimension. He indicates and describes three types of game structures which follow one another in the evolutionary development: the sense-motor game, the symbolic game and the structured game with rules.

In the sense-motor game, which occupies the first two years of life, the child reproduces without any particular objective a mental scheme which has just been acquired from interaction with his surroundings; the game during this phase consists prevalently in touching, manipulating.

During the next years the symbolic game gradually appears which consists in "pretending". With this solution the child can modify reality to his liking: a broom 
can become a soldier's horse, a pencil a barber's comb... objects lose their significance and take on another, whatever the child has decided to attribute to them in that moment. This type of game emerges due to the evolution of thought which progressively allows the child to distance himself from reality. During the next phase of development the game takes on a new distinctive feature, from individual it becomes collective. This phase is characterised by the fact that children manifest the desire to co-operate with other children, also for playing games, which before were played alone. Playing with others necessarily requires some negotiation, and thus emerges the need for rules which give clear indications for playing in a group.

Also Vygotsky (1972) recognises that the game plays an important role in child development, in fact he considers the game as the principal instrument of intellectual and relational development, a source of enjoyment and satisfaction of the child's desires. For this author there is no identifiable rigid sequence of development of the symbolic game, or from this to the game with rules, but only the use of these according to the situation and the individual necessities.

Bruner, lastly, underlines how playing games constitutes the principal activity of childhood. In his analysis he indicates the characteristics which distinguish games. He states that in a game we can observe how the means are more important than the end, the game in fact enables the individual to feel free from contextual limits, when we play we concentrate on what we are doing and not why we are doing it, we are absorbed in the game, and therefore free from everything that surrounds us. Another characteristic of the game according to Bruner's analysis lies in the fact that in a game unsuccessfulness is hardly present; since in the game there is no objective to be reached, no problem of failure, and therefore no frustration that could derive from this. The last characteristic of the game is its voluntary nature, this means that the child is free to play when, where and how he most wishes.

If we shift our attention from the time when a child plays in an atmosphere of total liberty to the school context, we can ask ourselves about the role that the game can play as a tool for favouring and encouraging learning, it is particularly useful to recall the concept of "game-like activities" which have many of the characteristics of the game but are different from it, while in the game the aim is part of the game, in game-like activities the aim is established by the adult who proposes the game with a specific educational intention (Staccioli, 2008).

Game-like activities, therefore, can represent for the teacher a didactic strategy to be used at work in order to pursue educational objectives.

\section{The game in the programme for primary schools}

After this definition of some of the theoretical-conceptual features of the game, it would be useful to shift our attention to the school programmes in order to understand if, and in what measure, they indicate the game as a tool to be used in educational practices. 
The school programme clearly defines the characteristics that distinguish the primary school, and states

The primary school aims at acquiring basic skills... The opportunity is offered to the children who attend to develop their cognitive, emotional, affective, social, and physical dimensions, and to acquire obligatory knowledge. It offers itself as a formative school which, by means of the alphabet of disciplines, gives the ability to exercise different powers of thought, thus providing an introduction to the development of reflective and critical thought.

The primary school, therefore, is the context within which pupils are offered the chance to mature and grow and the tools for entering into a constructive contact with the world.

With regard to the references which the programme contains referring to the game as a didactic instrument, it is possible to find a first reference in the section relating to the Italian language in which the game is recognised as having an important function for developing linguistic confidence.

By channelling the natural disposition of the pupil for games and invention, it will be possible to favour the gradual discovery of the means which language provides for the development of an ever wider awareness of the richness, flexibility and creativity of the language.

Another context in which the game is considered to constitute a valid instrument for working with pupils is that of foreign languages.

For learning other languages it will be necessary to use the intrinsic motivation to "play with language", playing with school friends and simulating roleplays. Songs, rhymes, physical movements from verbal prompts and games will enable the pupil, from the first stages of learning, to explore sounds and meanings and to master them in order to use them in a creative way.

In this case there is explicit reference to a particular type of game to be used, the roleplay, which, because of its particular characteristics and the specific mechanisms that it prompts, can perform an important didactic function.

The part of the text which talks more extensively about the game is obviously that relating to physical education.

Already at the start of this section, the document states

Participating in physical games and sports means sharing group experiences with other people, promoting the inclusion also of pupils with various difficulties, and emphasising the value of co-operation and team work. Games and sport, in fact, mediate and facilitate relationships and "meetings". In this way different forms of individual diversity become recognised and valued, and the risk that differences can be transformed into inequalities can be avoided.

Here the game becomes associated with social-relational competence, the game is in fact seen as a privileged channel to favour, promote and strengthen relationships between pupils, also and above all with the perspective of valuing possible differences. 
These aspects are taken up again a little later in the text

The pupil, through physical games and sport, which are privileged experiences that combine knowledge, knowing how to do, and knowing how to be, has constructed his own personal identity and the awareness of his own physical competences and limits.

He is able to utilise the communicative-relational aspects of the physicalmotor-sporting language, as well as the specific use of corporeality, of its functions and consolidation and development of motor and sporting abilities.

He acquires knowledge and competences relating to health education, prevention of illness and promotion of a correct lifestyle.

He acquires the capacity to integrate in a group, with which he shares and respects rules.

He acquires the capacity to accept and respect other people.

He acquires the capacity to take responsibility for his own actions, and to work for the common good.

He experiences the correct sports values (fair play) and the renunciation of any form of violence through the recognition and exercise of these values in different contexts.

The game therefore permits the pupil to become aware of his own body, of his own strengths and limits, it is a privileged channel for entering into contact with others and for developing positive relationships marked by collaboration. It is also a way to develop the first forms of contact with sport and with all the values and potentials that it possesses for the harmonious development of the subject.

A last reference to the game can be found in the section that deals with learning about mathematics, science and technology knowledge that contributes in a crucial way to the cultural formation of people and communities, developing the ability to bring together "thinking" and "doing" offering instruments suitable for perceiving, interpreting and linking natural phenomena, man-made concepts and artefacts, and daily events. The principles and practices of the sciences, mathematics and technology develop the capacity for criticism and judgement, the awareness that is needed to explain our own statements, the attitude for listening, understanding and appreciating arguments and points of view different from our own...The necessary components of this approach are posing and resolving problems, the ability to construct stories and interpretations and to develop arguments... Above all at primary school it is possible to use the game...

Also regarding the capacities and competences relating to the sphere of mathematics, the programmes indicate the game as a possible didactic instrument.

As well as these references which recall explicitly the game, the text often speaks of integrative didactics which aims at an active involvement of the subjects, which is able to involve and to motivate, and which avoids reactions of boredom all characteristics which describe game activities. 


\section{Use of the game in primary schools today: an empirical survey}

After dealing with the game at a theoretical level and examining the school programme text, it is important to concentrate now on what happens in reality in schools. A research was therefore planned with the aim of understanding if or how much the game is used in schools by teachers during the course of their didactic activity.

\section{The research}

Subjects involved.

The subjects of an entire primary school participated in this survey:

262 pupils ( 151 male and 111 female)

28 teachers ( 1 male and 27 female)

16 classes ( 3 first, 3 second, 3 third, 3 fourth and 4 fifth grades).

The pupils in the school are very mixed, there are pupils of different nationalities (prevalently from Bengal), and others from regions in the south of Italy.

\section{The tools}

2 questionnaires were prepared, one for the pupils and one for the teachers.

The questionnaire for the pupils was composed of 24 questions: 22 multiple choice and 2 open.

The questions were structured around three topic groups:

1. Why does the teacher proposes the game as a didactic instrument?

2. What is the attitude of the teacher when proposing a game activity?

3. What game does the teacher propose?

The questionnaire for the teachers was composed of 18 questions: 16 multiple choice and 2 open. The questions were again structured around the three topic groups named above to enable later comparison between the point of view of the teachers and that of the pupils.

It is interesting to note that during the questionnaire phase the teachers had different reactions. Some admitted to feeling ill at ease due to the game. These teachers tend to believe that it is appropriate to propose a game activity above all in the first years of school (first and second), but they think it is less appropriate in the more advanced classes (third, fourth and fifth). Others, on the other hand, were enthusiastic because finally they had the opportunity to deal with a theme that was important to them, and they were very interested in knowing the answers of the pupils. Some teachers, finally, had a neutral attitude towards the tool and towards the survey. 
Results

In this section I will show the results and discuss a part of them.

\section{A look at the whole: comparing pupils and teachers}

Both pupils and teachers agree on the fact that the game is a useful instrument for education.

The question asked to the pupils was the following:

In your opinion, could games help you to understand better the lessons taught by the teacher? $8 \%$ never.

$30 \%$ of the pupils interviewed answered always, $61 \%$ sometimes, and only

The question asked to the teachers was the following:

Do you think that games could be used as an efficient didactic instrument?

$31 \%$ of the teachers answered always, 69\% sometimes, and none of the teachers answered never.

It is interesting to note that the percentages in the answers are very similar if we compare the two groups. Both the teachers and the pupils, therefore, recognise that the game has an important role in learning.

What emerges when we study the real use of this instrument?

To this end, the question asked to the pupils was:

In your opinion, does the teacher use games?

The teachers were asked:

Do you use games in didactic activities?

The answers given by the two groups proved to be different. The first significant difference is that the option always was chosen by $24 \%$ of the pupils and only $8 \%$ of the teachers. Games are therefore considered to be more used in the opinion of the pupils than the teachers. One possible interpretation of this is the fact that the teachers integrate the game activity so well within their didactic practice that they are no longer aware of using it because they do not perceive it as separate from the more traditional teaching. Another significant difference lies in the option never. Also here the two groups are different; $29 \%$ of pupils chose this answer, while the teachers who said they never used games were only $8 \%$. A first possible interpretation of this difference is the fact that the pupils who answered never could not distinguish between the didactic game and the more traditional didactic. A second interpretation is possible: that the teachers use games in their didactic activities less than they believe. 


\section{Comparing teachers of Italian with teachers of Mathematics}

One of the questions asked was: does the subject you teach influence the didactic method that you choose to use? More specifically, it was asked: do teachers of Italian and teachers of mathematics use game as a didactic tool in equal measure or do they behave differently?

The data shows that the mathematics teachers have a much more favourable attitude to the use of game as a didactic instrument, with respect to their colleagues who teach Italian.

To the question:

Do you believe that game can be used as an efficient didactic tool?

Only $10 \%$ of Italian teachers answered always, compared to $50 \%$ of mathematics teachers. The answer sometimes was given by $90 \%$ of Italian teachers and by $50 \%$ of mathematics teachers. It is interesting to note that the answer never does not appear in the answers of the Italian or the mathematics teachers.

With regard to the use of the game as a didactic instrument, certain differences emerge between the two groups of teachers.

To the question:

Do you use games as a didactic activity?

Teachers of mathematics and Italian give the same percentage of answers for the option sometimes, which is chosen by both groups in $80 \%$ of cases. It is relevant, however, to observe that the teachers of mathematics choose the option always in $20 \%$ of cases, while $20 \%$ of the Italian teachers chose the option never. Therefore $20 \%$ of teachers have a negative attitude with regard to this instrument.

\section{Comparing the first grade (first and second) with later grades (third, fourth and fifth): the pupils}

All the pupils of the school recognise the importance of the game as an important learning activity.

Question: teacher?

In your opinion could games help you to understand better the lessons of the

The pupils in the first classes answered always in $39 \%$ of cases, sometimes in $52 \%$ of cases, and never in $9 \%$ of cases. The pupils in the older classes chose the answer always in $27 \%$ of cases, the answer sometimes in $65 \%$ of cases, and the answer never was chosen by only $7 \%$.

It can be confirmed that, in spite of the difference in age of the pupils, and the different contents of the lessons that the teacher proposes in primary school, the pupils recognise that the game is a valid instrument, not only when the pupils are still "little" but it always remains useful for teachers, regardless of the grade they are teaching. 
What really happens in the class? Does the teacher use games as much as the pupils would like? This aspect was investigated with the question:

In your opinion does the teacher use games?

The game, according to what the pupils say, is an instrument that teachers make use of. In the first grade there emerges a more frequent use of games (38\% chose always while in the older classes the option always was chosen by 17\%). The option sometimes was chosen by $53 \%$ in the older grades, but by $30 \%$ in the first classes. One fact worth noticing is that relating to the answer never. Both in the first grade and in the older grades, a third of the pupils (31\% in the first grade, $29 \%$ in the older grades) gave this answer.

This data can be interpreted in different ways. It is possible that in reality the teacher does not use it when working in class, or a second interpretation could be the following: the game is so well integrated into the normal didactic activity that the pupils cannot perceive it as something separate.

\section{Comparing the first grade (first and second) with later grades (third, fourth and fifth): the teachers}

Another aspect which is worth noticing is the difference in behaviour regarding the use of games, between teachers who work with "little" children, the ones in the first classes, and those who work with older children in the third, fourth and fifth classes of the primary school.

How do these two groups of Teachers value games as a didactic instrument?

To the question do you think that games can be used as an efficient didactic instrument? The teachers answered as follows.

$44 \%$ of teachers in the first grade thought that games could be always used, while in the older grades the answer always received $24 \%$ of votes. This answer is not surprising if we consider that in the first grade they try to take into account the type of structure that the children have come from, the infant's school, where games are the prevalent mode of education.

Regarding the answer sometimes, the percentages are the following: $56 \%$ for the teachers of the first grade, $76 \%$ for those of the older grades. None of the teachers, in either of the two groups, chose the answer never.

On the whole, we can confirm that both the groups consider that the game is a didactic instrument which can be widely used; this conviction is more evident among teachers who work with younger children.

With regard to use of this instrument in reality, investigated by the question: Do you use games in your didactic activities? the teachers answered as follows.

$89 \%$ of teachers in the first grade declared that they used games sometimes, compared to $82 \%$ in the older classes.

It is interesting to compare the data of these answers with the data of the preceding answers, above all regarding the teachers of the first grade and the answer 
always. It emerges, in fact, that in real didactic practice these teachers do not manage to use games as much as they would like. $44 \%$ of teachers in fact believe that it would be useful as a didactic instrument (answering the preceding question); but in reality only $11 \%$ use games (answering the present question).

\section{Comparing "expert" teachers with "beginner" teachers}

One variable which it is interesting to notice is the amount of experience of the teacher. Teachers who have been teaching for more than 29 years have been defined "expert", while "beginners" are those who have been teaching for less than 10 years.

The results which have emerged are very interesting. Counter to what one might expect, a higher percentage of the expert teachers believe that game is an efficient instrument for didactic activity than of the teachers with less experience. To the question

Do you believe that games can be used as an efficient didactic instrument?

the two groups answered as follows: always expert teachers $43 \%$, beginner teachers $14 \%$; sometimes expert teachers $57 \%$, beginner teachers $86 \%$; and the option never appears in neither group.

The explanation of this result could be connected to the experience of the expert teachers who, in the course of their professional career have had occasion to verify the validity of the instrument at work. Also in their favour is the greater possibility they have had to attend numerous refresher courses which can have contributed to making them more sensitive to the potentiality of games activities.

In effective practice, how do the two groups behave? The question asked was the following

Do you use games in your didactic activities?

$86 \%$ of both the experts and the beginners use games sometimes. However, $14 \%$ of the experts use games always, while the remaining $14 \%$ of the beginners never use it.

On the whole, then, the expert teachers are those who use educational games more in their daily practice. Probably, during the course of the years, the teachers have learned to appreciate educational games because they have mastered the contents of their own subjects and propose learning in ever more diverse modes. The beginner teachers, on the other hand, are not yet so sure of the contents of their subjects, and therefore feel safer using more traditional didactic methods.

\section{Concluding considerations}

Briefly, taking into consideration the most significant results of this research, we can confirm that 
- Both pupils and teachers agree on the fact that the game is a useful instrument on a didactic level.

- Mathematics teachers have a much more favourable attitude towards using games than their colleagues who teach Italian.

- The pupils recognise that games are useful, not only in the first classes when they are still "little", but it is a valid instrument which can be used by the teacher in his didactic activities independently of the class in which he is teaching.

- The game, according to what the pupils say, is an instrument which their teachers use.

- In the first classes more use is made of games.

- Teachers who have been working longer, and are therefore more "expert", contrary to what might be expected, proved to be more favourable to the use of games than their younger and less expert colleagues.

\section{Bibliography}

Bruner J.S., Jolly A., Sylva K. (1981), Il gioco. Ruolo e sviluppo del comportamento ludico negli animali e nell'uomo, Roma, Armando.

Caillois R. (1981), I giochi e gli uomini. La maschera e la vertigine, Milano, Bompiani.

Chateau J. (1961), Il fanciullo e il gioco, Firenze, La Nuova Italia.

Claparede E. (1955), Psicologia del fanciullo e pedagogia sperimentale. Lo sviluppo mentale, Firenze, Giunti Barbera.

Fink E. (1969), Oasi della gioia, Salerno, Rumma.

Fink E. (1991), Il gioco come simbolo del mondo, Firenze, Hopeful Monster.

Freud A. (1970), Normalità e patologia del bambino, Milano, Feltrinelli.

Freud A. (1977), Al di la del principio del piacere, Torino, Boringhieri.

Froebel F.W.A. (1960), L'educazione dell'uomo e altri scritti, Firenze, La Nuova Italia.

Huizinga J. (1964), Homo ludens, Torino, Einaudi.

Kaiser A. (1995), Genius ludi: il gioco nella formazione umana, Roma, Armando.

Klein M. (1970), La psicanalisi dei bambini, Firenze, Martinelli.

Klein M. (1978), La personificazione del gioco infantile, Torino, Boringhieri.

Manuzzi P. (2002), Pedagogia del gioco e dell'animazione, Milano, Guerini.

Millar S. (1974), La psicologia del gioco infantile, Torino, Boringhieri.

Piaget J. (1967), Lo sviluppo mentale del bambino, Torino, Einaudi.

Piaget J. (1972), La formazione del simbolo nel bambino, Firenze, La Nuova Italia.

Sclaunich M. (2005), "Il gioco come strumento per crescere, educare... e divertirsi" in Kermol E., Tessarolo M. (a cura di), Gioco e giochi. Tra comunicazione e nuove tecnologie, Padova, Cleup.

Staccioli G. (2008), Il gioco e il giocare, Roma, Carocci

Vygotsky L. (1972), Immaginazione e creatività infantile, Roma, Editori Riuniti. 
Winnicott D.W. (1974), Gioco e realtà, Roma, Armando.

Metodički obzori 6(2011)2

Pregledni rad

UDK: 371.695:373.3

Primljeno: 30.8 .2010$.

\title{
IL GIOCO COME STRUMENTO PER LA PROMOZIONE DELL'APPRENDIMENTO. UNA RICERCA NELLA SCUOLA PRIMARIA
}

\author{
Magda Sclaunich \\ Ricercatore presso la \\ Facoltà di Scienze della Formazione di Trieste (Italy) \\ e-mail: sclaunic@units.it
}

\section{Riass unto}

Il presente lavoro propone una particolare strategia metodologica didattica, il gioco, che è stato affrontato su tre diversi livelli.

Livello 1. Nel primo livello si è cercato di delineare, se pur in modo sintetico, alcuni tratti teorico-concettuali del gioco. In una prospettiva storica, a partire da Froebel sono stati richiamati alcuni autori che, nell'ambito della storia dell'educazione, hanno riconosciuto al gioco una valenza didattica-educativa e lo hanno proposto come valido strumento per promuovere e potenziare la crescita dei soggetti.

Livello 2. Nel secondo livello si è ritenuto utile analizzare il testo programmatico attualmente in vigore in Italia (Le "Indicazioni per il curricolo") per capire quale importanza questo documento attribuisce al gioco come strumento didattico.

Livello 3. Nel terzo livello questa tematica è stata affrontata secondo una prospettiva empirica. E' stato infatti condotto uno studio sul campo che ha coinvolto insegnanti e alunni di un'intera scuola per cercare di capire quanto il gioco viene ritenuto importante e quanto viene realmente utilizzato come strumento didattico da parte degli insegnanti all'interno della scuola primaria.

Sono stati predisposti 2 questionari a scelta multipla, uno per gli alunni e uno per gli insegnanti.

I dati hanno messo in evidenza che

- Sia gli alunni che gli insegnanti concordano sul fatto che il gioco è uno strumento utile sul piano didattico.

- Gli insegnanti di matematica hanno un atteggiamento decisamente più favorevole all'uso del gioco come strumento didattico rispetto ai colleghi che insegnano italiano.

- Gli allievi riconoscono che il gioco non è utile soltanto nelle prime classi quando sono ancora "piccoli" ma è un valido strumento a cui l'insegnante può ricorrere nella sua attività didattica indipendentemente dalla classe in cui insegna. 
- Il gioco, stando a quel che dicono gli alunni, è uno strumento di cui gli insegnanti fanno uso.

- Nelle prime classi gli insegnanti utilizzano il gioco in misura maggiore.

- Gli insegnanti con maggiore anzianità di servizio, e quindi più "esperti", contrariamente a quanto si potrebbe pensare, risultano più favorevoli all'utilizzo del gioco rispetto ai colleghi più giovani e inesperti.

Parole chiave: gioco, apprendimento, scuola primaria, programmi scolastici, strategie didattiche 